総説 一日本歯周病学会学術賞受賞一

歯周組織再生を目指す新規サイトカイン療法と細胞治療の基礎研究 加治屋幹人

広島大学大学院医系科学研究科歯周病態学研究室

キーワード：歯周組織再生, サイトカイン療法, 細胞治療, 間葉系幹細胞

\section{1.はじめに}

歯周炎は, 細菌感染と宿主の免疫応答の結果生じる 炎症性組織破壊疾患であり, セメント質・歯周勒带・ 歯槽骨からなる歯周組織が罣失する。その歯周炎治療 として, 徹底的な感染源除去が行われる。しかし, 感 染源除去によって炎症を軽快させ, 組織破壊の進行を 停止することができるが, 失われた歯周組織が再生す ることは少ない。歯周組織が㩽失した状態では, 歯肉 ラインの乱れによる清掃性低下と, 支持組織が不足す ることに起因する二次性咬合性外傷を引き起こすた め, 歯周炎を再発しやすい。したがって, 歯周炎の完 治のためには, 失われた歯周組織を再生させる歯周組 織再生療法が必要となる。

歯周組織再生療法の開発研究について, 1970 年代か ら骨移植が中心に検討され 1$) ， 1980$ 年代には遮蔽膜を 用いた組織再生誘導法 (guided tissue regeneration method：GTR method)が樹立された2)。さらに, 1990 年代にはいると, ブ夕歯胚から採取・精製したエナメ ルマトリックスタンパクを用いた歯周組織再生療法が 開発された3)。そして，2000 年代以降には，バイオマ テリアルや, サイトカイン，もしくは幹細胞による歯 周組織再生療法の開発基礎研究が隆盛を極め, 現在で は, 遺伝子組み換元塩基性線維芽細胞增殖因子（basic fibroblast growth factor：bFGF）を医薬品として投与 するサイトカイン療法が確立され, 間葉系幹細胞を移 植する細胞治療の臨床試験が複数実施されている。

しかしながら，有望な新規技術が樹立されつつある 現在に扔いても, 安全で, より効果的で, 予知性の高 い歯周組織再生療法を, すべての歯周炎患者に提供す

\footnotetext{
連絡先 : 加治屋幹人

T734-8553 広島県広島市南区霞 1-2-3

広島大学大学院医系科学研究科歯周病態学研究室

E-mail : mkajiya@hiroshima-u.ac.jp

doi : 10.2329/perio.63.105
}

るためには，基礎研究で解決すべき課題が数多く残さ れている。そこで本稿では, サイトカイン療法・細胞 治療法の開発経緯と現状について概説し，より有効な 歯周組織再生療法開発のための問題解決策について, 著者の研究グループの取り組みをまじえて紹介する。 さらに, 国内外の最新の研究成果も俯瞰しながら, 今 後取り組むべき研究課題について考察する。

\section{2. サイトカイン療法と細胞治療法の相違点・ 共通点}

サイトカインを用いた組織再生療法の基本原理は, 欠損組織に存在する細胞の機能を活性化することで, 組織再生を促進するものである。したがって，歯周組 織再生療法としての適応症は, 制御するべき機能的な 細胞が残存する, 垂直性骨欠損や I II 級根分岐部病 変などの限局型歯周組織欠損症例となる。これより広 範な欠損症例 (水平性骨欠損や III 級根分岐部病変) で は, 組織再構築を担う細胞数が絶対的に不足するため, 生体外からその機能的な細胞，すなわち未分化前駆細 胞を移植する細胞療法が適応となる。この適応症の違 いをよく理解することで, サイトカイン療法と細胞治 療のそれぞれに適切な研究デザインを設計することが 可能になる。

一方, 組織再生療法を開発するためには, 生体の組 織再生，もしくは組織修復の過程を模倣することが合 理的な戦略であるといえる。このことは, サイトカイ ン療法・細胞治療法のいずれの開発研究に扔いても共 通した考え方となる。例えば，すでに歯周組織再生療 法の医薬品として上市されている, 遺伝子組み換え bFGF は，創傷治癒・血管新生・肧発生を制御する步 イトカインである4)。また, 中肧葉由来組織の発生起源 となる間葉系幹細胞 (Mesenchymal stem cells: MSCs)5）を移植する基礎研究・臨床試験では，有望な 歯周組織再生効果が多数報告されている。したがって, より有効なサイトカイン療法・細胞治療法の開発のた めには, 発生学等の基礎研究分野をより梁く理解し, その知見を応用することも重要な方策の一つとなる。 


\section{3. サイトカイン療法の現状と展望}

サイトカイン療法は, 1970 年代から 80 年代にかけ て，遺伝子工学の技術が飛躍的に発展し，遺伝子組み 換えタンパクを容易に作製可能になったことによっ て，医療分野で大きな期待を集めた。この流れにした がい, 歯周組織再生療法開発研究においても, 多種の サイトカインが検討されてきた。たとえば，血小板か ら放出され組織創傷治癒を促進する血小板由来増殖因 子 (platelet-derived growth factor : PDGFG) の $\mathrm{BB}$ アイソフォーム (PDGF-BB) が, 歯周組織再生を促進 する可能性が示唆され6-8), $\beta$ リン酸三カルシウム（ $\beta$ tricalcium phosphate： $\beta$-TCP）と PDGF-BB を組み合 わせた医療機器が米国で販売承認を受け，臨床応用さ れている。一方，本邦では，強力な血管新生・歯根膜 細胞増殖促進効果を発揮するリコンビナント bFGF が，正確に設計された複数回の臨床治験を経て，歯周 組織再生の医薬品として承認され臨床の場で利用され ている9-11)。今後は, bFGFに骨補填材などを組み合わ せることで, より予知性の高い歯周組織再生療法を開 発する研究が進められると予想される。

上述のとおり，遺伝子組み換え bFGF が医療機器で はなく, 医薬品として承認されていることは, サイト カイン療法開発研究が一つの大きな区切りを迎えたこ とを示す。しかし，歯周組織の恒常性維持には, bFGF に限らず，多様なサイトカインが関与する12)。した がって, bFGF とは異なる作用機序で, 歯周組織再生療 法に有効となるサイトカインが新たに同定される可能 性は十分にありえる。

著者らの研究室では，歯の発生時期に，歯根膜腔相 当部に多量に発現する脳由来神経栄養因子（brainderived neurotrophic factor : BDNF) が, 歯周組織再 生療法として有効なサイトカインとなりうると仮説を 立て基礎研究を実施してきた。動物実験レベルでは, ビーグル犬 III 級根分岐部欠損モデルに対して，アテ ロコラーゲンゲル，もしくはヒアルロン酸ゲルを担体 としたBDNF の投与が, 効果的な歯周組織再生を誘導 した13,14)。この動物実験での成果を受け, BDNFによ る歯周組織再生の分子メカニズムを調べるための in vitro 研究を行った。特に, 神経系の研究から, BDNF に対して，その高親和受容体 TrkB と低親和受容体 p75 が存在し, 各々が特異的なシグナル伝達経路を活 性化させ, 細胞増殖・分化・アポトーシス等を制御し ていることが報告されていた15)。そこで，この TrkB シグナルと p75 シグナルに注目しながら, 歯周組織構 成細胞に対するBDNF の影響を検討した。その結果, 歯根膜細胞やセメント芽細胞，もしくは血管内皮細胞 など歯周組織再構成に重要な役割をになう間葉系細胞 群では，TrkB 受容体を介した Erk/Ak シグナルが細
胞増殖・硬組織形成・血管新生等を促進することが示 された16-18)。さらに興味深いことに, これらの間葉系 細胞群では役割が不明であった p75 受容体が，外胚葉 系である歯肉上皮細胞に高発現しており，BDNF 刺激 を受けると p75-JNK シグナルが TrkB-Erk/Akt シグ ナルを阻害しながら，増殖抑制・アポトーシスを誘導 することを見出した19)。これらの結果から, BDNF による歯周組織再生メカニズムは，歯肉上皮細胞の夕゙ ウングロースを抑制し，歯根膜細胞などの増殖 - 分化 を活性化するという二面的効果によるものであると考 えられた。

この, BDNF の細胞増殖に関わる二面的効果による 歯周組織再生機序は, bFGF とは明らかに異なる。 bFGF は歯肉上皮細胞に対しても細胞増殖促進効果が あるが，それをはるかに上回る歯根膜細胞の増殖を誘 導する20,21）ため，ロバストな歯周組織再生を達成す る。この BDNF と bFGF の作用機序の違いから, 各サ イトカインには最適な適応症・投与方法があると考え られた。BDNF は歯肉上皮細胞に負の効果を発揮する ため, scaling and root planing (SRP) のみで感染源除 去が可能な小規模歯周組織欠損に対して, BDNF を直 接投与することで歯肉上皮のダウングロースを抑制し ながら歯周組織再生を達成できると考え実験を行っ た。その結果，ビーグル犬絹糸結紮歯周炎モデルにお いて, 絹糸を除去し SRP を実施直後に, 歯周ポケット から $\mathrm{BDNF}$ を直接投与したところ, SRP のみを行った 群と比較して，長い上皮付着が生じず効果的な歯周組 織再生が誘導された22)。

このように, bFGFや BDNF 等のサイトカインに は，当然ながら，特有の受容体とそれが生じるシグナ ル伝達経路が各々存在する。BDNF 以外にも, トラン スフォーミング増殖因子（transforming growth factor: TGF)，インスリン様増殖因子 (insulin-like growth factor：IGF), 増殖分化因子 (growth differentiation factor：GDF）などの他のサイトカインも歯周 組織再生療法における有効性が報告されているが23), これら bFGF 以外のサイトカインについても，そのシ グナル伝達経路を詳細に把握することで，新規的な歯 周組織再生サイトカイン療法として応用される可能性 が高い。たとえば，各種サイトカインを組み合わせる ことで，歯周組織再生のカスケードを最も効率的に活 性化させる方法が挙げられる。あるいは，次世代シー クエンサー技術の急速な発展に伴い, 患者個人のゲノ ムを容易に解読可能な現在であれば，患者ごとの受容 体・シグナル伝達経路の活性化パターンを事前に予測 し，各人に最適なサイトカインを投与するテーラーメ イド歯周組織再生療法が実現可能になるかもしれな い。さらに，受容体・シグナル伝達経路の分子メカ二 ズム解明研究によって，有望なシグナル伝達経路を活 性化可能な低分子化合物が作製可能になる。このこと 
は, サイトカイン療法のコスト低下を可能とする。実 際に，著者らの研究グループでは，BDNFの TrkB 結合部位を模倣する低分子化合物 LM22A-4 が, BDNF と同様に TrkB-Erk シグナルを介した細胞分化 誘導効果を発揮することを報告している24)。p75 受容 体結合部位を模倣する低分子化合物も同定できれば, それらを組み合わせた安価な歯周組織再生療法が提供 可能になるかもしれない。

以上のことから，今後のサイトカイン療法は，医薬 品として承認された bFGF を中心に展開していくと 考えられるが, 一方で，その他のサイトカインについ ての分子生物学的基礎研究を発展させ，新たなサイト カイン療法を模索し続けることが重要である。

\section{4. 細胞治療の現状と展望}

前述したように，組織傷害の規模が広範で，残存組 織中の機能的な細胞数が絶対的に不足する非可逆的な 状態に対して，生体外から細胞を供給する細胞治療法 が必要となる。歯周炎患者の場合, 1 壁性骨欠損, III 級根分岐病変, あるいは水平性骨欠損などが挙げられ る。

歯周組織再生療法として供給するべき細胞は, セメ ント質一歯周勒带一歯槽骨といった複数の組織を再構 成可能な，多分化能を有した幹細胞が最適である。そ こで，多分化能・自己増殖能を有する MSCs が骨髄か ら同定され25)，その骨髄由来 MSCs 移植の歯周組織再 生効果がビーグル犬を用いた大動物レベルで初めて報 告されて以来26)，MSCsを用いた歯周組織再生細胞療 法の開発研究が世界中で加速した。実際に，この十数 年というわずかの期間で，MSCsに関する重要な知見 が数多く報告された。代表的なものとして, MSCs は多 分化能のみならず，細胞保護 ·免疫制御能も有してお り，この作用によって残存組織中の細胞機能制御を行 うことが挙げられる27)。さらに，骨髄のみならず，脂 肪や臍帯，もしくは骨膜などにも多分化能・自己増殖 能の高い MSCs が存在し, それらが医療応用可能であ ることが示されたことによって，多くの研究者の注目 を集めた。特に, 2004 年には, 歯根膜から MSCs が分 離・同定された28)。歯根膜由来 MSCs は, 歯周組織の 起源となる細胞であるため, 歯周組織再生細胞療法に おいては, その他の組織由来 MSCs などと比較してよ り適切な細胞ソースと期待できる。

このような MSCs に関する多くの基礎研究の成果 に基づき，国内外で，患者自身の MSCs を生体外で分 離・拡大培養し, 歯周組織欠損部に移植する臨床試験 が複数行われている29)。特に本邦では, 法令を遵守し, よく設計された研究計画に基づいた高品質な歯周組織 再生細胞療法の臨床試験が多く実施されている。東京 医科歯科大学の研究グループは, 自己歯根膜幹細胞に
細胞シート培養技術を応用した臨床試験によって，そ の安全性・有効性を示し30，現在では，ドナー由来歯 根膜幹細胞を用いた同種他家移植の臨床試験を行って いる。また，大阪大学では脂肪由来 MSCsを，フィブ リンゲルを担体とする自家移植の臨床試験が完遂され ている。さらに，順天堂大学では自己脂肪由来 MSCs と多血小板血漿を混和して移植する臨床試験が開始さ れている。その他, 骨膜細胞シートの移植が新潟大学 でも実施されてきている31)。bFGF のサイトカイン療 法としての成功に続き，本邦の科学技術に基づいた， MSCsによる歯周組織再生細胞療法を実現する日が着 実に近づいているといえる。

しかしながら, 細胞療法に期待される治療効果は, 極論すると，いかなる大規模歯周組織欠損に対しても 決定的な組織再生を誘導するものである。また，どれ ほど高い治療効果を発揮する細胞療法が樹立されたと しても，経済的な妥当性が無くては社会実装すること は難しい。さらに，実際の医療技術として利用するた めには，高い予知性と，万全の安全性を有しているこ とが欠かせない。すなわち，歯周組織再生細胞治療法 を実現するためには，ヒトレベルでの安全性・有効性 を評価する臨床試験と併行して, 治療効果・経済性 · 予知性・安全性をより高めていくための基礎研究が必 要といえる。

著者の所属する広島大学では，2000 年代初期に，歯 周炎患者の自己骨髄由来 MSCs をアテロコラーゲン ゲルに混和して移植する臨床試験を実施した。その結 果，すべての被験者に有害事象は認められず，自己骨 髄 MSCs 移植の安全性が示された。また, GTR 法等の 標準治療と同等以上の歯周組織再生効果が得られた が, III 級根分岐部病変などの大規模欠損患者に対して は期待したほどの組織再生が生じなかった。そこで, 骨髄 MSCs 移植の治療効果を向上させるために, 足場 材料の改善を考え，骨伝導能と吸収性のバランスに秀 でた $\beta$-TCP を併用し，ビーグル犬 III 級根分岐部欠損 への移植実験を行った。期待した通り， $\beta$-TCP を用い た MSCs 移植群において, 移植 4 週間後という比較的 早期に欠損部を満たす歯槽骨形成が得られた。しかし， 新生骨内部には $\beta$-TCP が貯留し続け, 一部には歯槽骨 と歯根が癒着するアンキローシスが観察された32)。こ の結果は， $\beta$-TCP は，骨再生の足場として有効である 一方，生体にとってやはり異物として認識されアンキ ローシス等の代謝異常の原因となる可能性を示唆して いた。また，長期間残留する $\beta$-TCP は，臨床的にみる と感染源リスクといえる。

このような結果を受け, 著者らは, MSCs を用いた歯 周組織再生療法の治療効果を根本的に向上させるため の基礎研究に立ち返ることとした。その治療効果向上 のための方策の代表的なものが，新規バイオマテリア ル開発研究である。特に, $\beta$-TCPよりもさらに吸収性 
に優れ, 細胞接着・細胞保護効果が高く, サイトカイ ン（もしくは, ペプチド・低分子化合物・核酸）等の 骨誘導因子を組み込んだバイオマテリアルの樹立を目 指した研究は, 再生医療分野において大きな存在感を 示している。口腔領域では，炭酸アパタイトを主成分 とする骨補填材 (サイトランスグラニュール $($ 等が上 市され, 臨床の場で優れた骨再生効果を発揮している。 このバイオマテリアル開発研究については, 優れた総 説33,34)で詳説されているためそちらを参照されたい。

しかし著者らは，もう一つの治療効果改善のための 方策として，人工足場材料を用いない Scaffold-free の MSCs 移植療法開発研究を選択した。Scaffold-free の 利点は, 人工材料の吸収等の問題を回避できることに 加えて, 細胞の生理活性に重要な細胞間接着や, 細胞一 細胞外基質（Extracellular matrix：ECM）の結合を適 切に保持した状態で MSCs を移植できることである。 Scaffold-free 移植の代表的なものとして, 細胞シート や35), おもに細胞間接着力によって構築される細胞ス フェロイドなど36)が多く研究されていたが，さらなる 改良策として著者らは，3次元的間葉系幹細胞集塊 Clumps of MSCs/ECM complexes (C-MSCs) を独自に 開発した。

直径 $1 \mathrm{~mm}$ ほどの立体的細胞集塊である C-MSCs は, MSCs と細胞自身が産生した ECM から構築され, 人工足場材料を用いることなく実質欠損部に直接移植 できる37)。直径 $1 \mathrm{~mm}$ の細胞塊を複数個組み合わせる ことで，いかなる形態の欠損部に対しても，過不足の ない正確な細胞の移植が出来ることは一つの特徵とい える。また，人工足場材料の吸収の過程が不要となる ため, C-MSCs の移植は, 人工材料を担体とした MSCs 移植よりも速やかな硬組織再形成を達成する37)。ま た，移植前の培養条件によって，C-MSCsにおける COL1 等の ECM 産生量を増加させておくことで，よ り高い骨・歯周組織再生効果を発揮させられることを ラット頭蓋冠欠損モデル・ビーグル犬 III 級根分岐部 歯周組織欠損モデルに対する移植実験から明らかにし た37,38)。これらの動物実験での成功を受け, ヒトCMSCs の臨床応用を想定し, 異種動物タンパク不含. 血清不含の Xeno-free/Serum-free 条件でヒト骨髄由 来 MSCs から C-MSCs を作製し, 免疫不全 SCID マウ ス頭蓋冠欠損モデルに対する移植実験を行った39)。ヒ ト C-MSCs の骨欠損部への移植は, 予想した通り効果 的な骨再生を誘導した。その組織再生形成過程におけ る移植されたヒト細胞と宿主のマウス細胞の振る舞い を観察するために, ヒトVimentin 特異抗体を用いた 免疫染色を行ったところ，移植されたヒト細胞は，デ ンドライトな突起を有する骨細胞にまで分化し，宿主 のマウス細胞由来骨細胞と互いにネットワーク形成を しながら新生骨を形成していることが確認された。さ らにその新生骨を長期間観察したところ，移植された
ヒト細胞は次第に消失していき，宿主マウス由来の骨 細胞のみとなった。また，ヒトC-MSCs を形作ってい たCOL1 タンパクが, 骨再構築の足場となっているこ とも観察された。以上のことから，ヒトC-MSCsの移 植は, 従来の人工足場材料を用いた MSCs 移植とは異 なる，ユニークかつ効果的な歯周組織再生が達成でき ると考えられ, 現在, ヒトレベルでの安全性・有効性 を検証する臨床試験を計画中である。

この 3 次元細胞集塊培養技術は, 治療効果のみなら ず, 再生医療の実現に向けて様々な長所を有している。 例えば，C-MSCsはその形態や細胞活性を損なわずに 凍結保存可能であり，実際に，液体窒素タンクにて 6 か月間の凍結保存を経た C-MSCs の移植が, 凍結保存 をされていない通常の C-MSCs と同等の骨再生を促 進することを，ラットを用いた実験で示した40)。さら に，IFN- $\gamma$ 刺激を受けた MSCs は免疫調節酵素 IDO の発現を高め, 免疫抑制を行う41）という性質を応用 し，IFN- $\gamma$ 前処理したヒト C-MSCs を作製（C-MSCs$\gamma$ ）したところ，C-MSCs- $\gamma$ はヒト T細胞の活性化を抑 制し，さらにマウス頭盍冠欠損モデルへの異種移植に おいて，移植拒絶を逃れながら骨再生を促進すること を見出した42)。このように，凍結保存可能であり，免 疫制御能を向上させ移植拒絶を回避することができる 細胞集塊 C-MSCs は，ドナー由来のMSCs から事前に C-MSCs として加工・備蓄し, 患者必要時に迅速に提 供可能な細胞製剂としての提供可能性を示唆したとい える。この C-MSCs 細胞製剂化によって, 細胞加工に 関わる品質管理検査を十分に実施可能となり，培養期 間・コストの縮小にもつながる。また, 加齢や遺伝子 疾患などの原因でMSCsの機能そのものが低下して いる患者にも適応可能な再生医療となりえる。今後は, 細胞製剤化に向けてどのような組織由来の MSCs か ら C-MSCs を備蓄していくかが次の研究課題となる。 その細胞ソースについては, 廃棄資源となりやすい脂 肪や臍带が骨髄と比べて利用しやすい。また, 組織恒 常性の観点からは, 歯根膜由来幹細胞を備蓄すること が歯周組織再生療法に有効となりえる。さらに，近年 では, iPS 細胞や $\mathrm{ES}$ 細胞などからあらゆる細胞が手に 入れられる。理論的には, 歯周組織, さらには歯根膜 細胞の起源となる神経堤細胞由来 MSCs を用いた細 胞治療も実現可能といえる。未分化細胞を確実に取り 除く検查法・誘導法が樹立されれば，これら多能性細 胞由来 MSCs も有効な細胞ソースとなりえる。この多 能性細胞からの細胞供給の概念については, 2018 年の Dr. Zhao と 2020 年の Dr. Ouchi の総説 43, 44) が詳しい ので,これらの細胞研究に取り組む前には一読された い。

従来の二次元培養と異なり, C-MSCs は浮遊培養さ れる 3 次元的な細胞塊であるため, これまで報告され ている MSCsの基本性質とは大きく異なることが予 
想された。そこで，場の硬さなど，細胞周囲の微小環 境の状態を感知し, 生化学信号として伝達するメカノ シグナルトランスダクションに焦点をあて, C-MSCs の多分化能や細胞保護因子分泌能についての解析を 行った。その結果, 浮遊立体培養は, プラスチック培 養皿上の二次元状態とは異なり，1)場の硬さに応答す る $\mathrm{YAP} / \mathrm{TAZ}$ メカノシグナルが抑制され, 脂肪・軟骨 分化運命に向かいやすいこと45)，2)培養条件によって は C-MSCs の COL1 産生を向上させ, ECM の硬化に よる YAP/TAZ メカノシグナルを活性化させ, それに 伴った骨分化運命に誘導させられること45)，3）浮遊状 態になると p38/JNK-c-fos-COX2 シグナルカスケード による PGE2 産生が立進し, これが細胞保護作用を発 揮すること46)，を明らかにした。現在，1）と2）の知 見を応用し，ゲル包埋培養等を併用することでC$\mathrm{MSCs}$ 周囲の硬さ調節と YAP/TAZ 制御を行い, 生体 外で, C-MSCs を骨様組織そのものにまで誘導するこ とに取り組んでいる。生体外で骨様組織が作製可能性 になれば，自家骨移植に相当する細胞加工製品が提供 可能になるため, 歯周組織再生療法の有効性がますま す高まると期待している。また，3）の知見については, 細胞加工施設から患者への出荷判定に用いる品質管理 マーカーの一つとして利用することを検討している。

以上のことから，MSCs を用いた歯周組織再生細胞 療法は, 2000 年代初期と比較して明らかに実現味を帯 びてきているが，細胞治療に期待される治療目標は極 めて困難なケースが想定されるため, 治療効果・安全 性・予知性・コス卜等の改善させる基礎研究が不可欠 である。

\section{5. まとめ}

歯周組織再生療法として, サイトカイン療法と細胞 治療法の二つが注目を集めているが, これらの適応症 やその開発段階は明らかに異なる。サイトカイン療法 は，医薬品として承認された bFGF を中心として，さ らに適応拡大やコスト低下, その他技術との併用療法 開発が進むと予想される。ただし, その他のサイトカ インについて, 徹底的な分子生物学的レベルでの理解 を深めることで, bFGF とは異なる作用機序の, 異なる 適応症をもったサイトカイン療法が実現する可能性が ある。

細胞治療は,これまでに有効な治療法のない重度歯 周炎患者に対する決定的な解決策として期待できる。 一方で，細胞加工製品を医薬品として提供するために は, 安全性・品質管理が化合物と比較して極めて難し い。大きな困難をともなうが, 正確な臨床試験を地道 に重ねていくしかない。さらに, その臨床試験の結果 を冷静に分析し, さらなる改良法を提供する基礎研究 をつねに伴走させていく必要があると考えられる。
今後, 歯周病学を専門とする多くの研究者が一丸と なり，世界に先駆けた革新的歯周組織再生療法を実現 する日を期待している。

\section{謝辞}

稿を終えるにあたり，再生医療研究の基礎から臨床まで 広い視野でご指導いただきました栗原英見名誉教授に心か ら感謝いたします。また, 大学院生時代から, 基礎研究の 素晴らしさを学ばせていただいた柴秀樹教授に深く御礼申 し上げます。また, 本研究の遂行にあたり, 広島大学大学 院医系科学研究科歯周病態学研究室の皆様には, 多大なご 支援を賜りました。特に, サイトカイン療法研究は, 武田 克浩講師, 佐々木慎也助教, 松田真司助教の, 細胞治療研 究に関しては河口浩之教授の, 独創的な研究成果とそれに 基づくご助言の賜物です。さらに, サイトカイン療法研究 は柏井圭博士に, 細胞治療研究は, 橘高瑞穂博士, 竹下慶 博士, 竹脇学博士, 小松奈央博士, 本池総太博士の尽力の もと進めることができました。ここに感謝の意を表します。

今回の論文に関連して，開示すべき利益相反状態はありませ ん。

\section{文献}

1) Moskow BS, Karsh F, Stein SD: Histological assessment of autogenous bone graft. A case report and critical evaluation. J Periodontol, 50: 291-300, 1979.

2) Nyman $S$, Lindhe J, Karring T, Rylander H: New attachment following surgical treatment of human periodontal disease. J Clin Periodontol, 9: 290-296, 1982.

3) Brookes SJ, Robinson C, Kirkham J, Bonass WA: Biochemistry and molecular biology of amelogenin proteins of developing dental enamel. Arch Oral Biol, 40: 1-14, 1995.

4) Hui $Q$, Jin Z, Li X, Liu C, Wang X: FGF Family: From Drug Development to Clinical Application. Int J Mol Sci, 19: 2018.

5) Phinney DG, Prockop DJ: Concise review: mesenchymal stem/multipotent stromal cells: the state of transdifferentiation and modes of tissue repair--current views. Stem Cells, 25: 2896-2902, 2007.

6) Lynch SE, Wisner-Lynch L, Nevins M, Nevins ML: A new era in periodontal and periimplant regeneration: use of growth-factor enhanced matrices incorporating rhPDGF. Compend Contin Educ Dent, 27: 672-678; quiz 679-680, 2006.

7) Ronnstrand L, Heldin $\mathrm{CH}$ : Mechanisms of plateletderived growth factor-induced chemotaxis. Int J Cancer, 91: 757-762, 2001.

8) Lynch SE, Williams RC, Polson AM, Howell TH, 
Reddy MS, Zappa UE, Antoniades HN: A combination of platelet-derived and insulin-like growth factors enhances periodontal regeneration. J Clin Periodontol, 16: 545-548, 1989.

9) Kitamura M, Akamatsu M, Kawanami M, Furuichi Y, Fujii T, Mori M, Kunimatsu K, Shimauchi H, Ogata Y, Yamamoto M, Nakagawa T, Sato S, Ito K, Ogasawara T, Izumi Y, Gomi K, Yamazaki K, Yoshie H, Fukuda M, Noguchi T, Takashiba S, Kurihara H, Nagata T, Hamachi T, Maeda K, Yokota M, Sakagami R, Hara Y, Noguchi K, Furuuchi T, Sasano T, Imai E, Ohmae M, Koizumi H, Watanuki M, Murakami S: Randomized Placebo-Controlled and Controlled Non-Inferiority Phase III Trials Comparing Trafermin, a Recombinant Human Fibroblast Growth Factor 2, and Enamel Matrix Derivative in Periodontal Regeneration in Intrabony Defects. J Bone Miner Res, 31: 806-814, 2016.

10) Kitamura M, Akamatsu M, Machigashira M, Hara Y, Sakagami R, Hirofuji T, Hamachi T, Maeda K, Yokota M, Kido J, Nagata T, Kurihara H, Takashiba S, Sibutani T, Fukuda M, Noguchi T, Yamazaki K, Yoshie H, Ioroi K, Arai T, Nakagawa T, Ito K, Oda S, Izumi Y, Ogata Y, Yamada S, Shimauchi H, Kunimatsu K, Kawanami M, Fujii T, Furuichi Y, Furuuchi T, Sasano T, Imai E, Omae M, Yamada S, Watanuki M, Mura kami S: FGF-2 stimulates periodontal regeneration: results of a multi-center randomized clinical trial. J Dent Res, 90: 35-40, 2011.

11) Kitamura M, Nakashima K, Kowashi $Y$, Fujii T, Shima uchi H, Sasano T, Furuuchi T, Fukuda M, Noguchi T, Shibutani T, Iwayama Y, Takashiba S, Kurihara H, Ninomiya M, Kido J, Nagata T, Hamachi T, Maeda K, Hara Y, Izumi Y, Hirofuji T, Imai E, Omae M, Watanuki M, Murakami S: Periodontal tissue regeneration using fibroblast growth factor-2: randomized controlled phase II clinical trial. PLoS One, 3: e2611, 2008.

12) Morand DN, Davideau JL, Clauss F, Jessel N, Tenenbaum H, Huck O: Cytokines during periodontal wound healing: potential application for new therapeutic approach. Oral Dis, 23: 300-311, 2017.

13) Takeda K, Sakai N, Shiba H, Nagahara T, Fujita T, Kajiya M, Iwata T, Matsuda S, Kawahara K, Kawaguchi $\mathrm{H}$, Kurihara H: Characteristics of high-molecularweight hyaluronic acid as a brain-derived neurotrophic factor scaffold in periodontal tissue regeneration. Tissue Eng Part A, 17: 955-967, 2011.

14) Takeda K, Shiba H, Mizuno N, Hasegawa N, Mouri $Y$, Hirachi A, Yoshino H, Kawaguchi H, Kurihara H: Brain-derived neurotrophic factor enhances periodontal tissue regeneration. Tissue Eng, 11: 1618-1629,
2005.

15) Blochl A, Blochl R: A cell-biological model of p75NTR signaling. J Neurochem, 102: 289-305, 2007.

16) Matsuda S, Fujita T, Kajiya M, Takeda K, Shiba H, Kawaguchi H, Kurihara H: Brain-derived neurotrophic factor induces migration of endothelial cells through a TrkB-ERK-integrin alphaVbeta3-FAK cascade. J Cell Physiol, 227: 2123-2129, 2012.

17) Kajiya M, Shiba H, Fujita T, Takeda K, Uchida $Y$, Kawaguchi H, Kitagawa M, Takata T, Kurihara H: Brain-derived neurotrophic factor protects cementoblasts from serum starvation-induced cell death. J Cell Physiol, 221: 696-706, 2009.

18) Kajiya M, Shiba H, Fujita T, Ouhara K, Takeda K, Mizuno N, Kawaguchi H, Kitagawa M, Takata T, Tsuji $\mathrm{K}$, Kurihara H: Brain-derived neurotrophic factor stimulates bone/cementum-related protein gene expression in cementoblasts. J Biol Chem, 283: 1625916267, 2008.

19) Kashiwai K, Kajiya M, Matsuda S, Ouhara K, Takeda K, Takata T, Kitagawa M, Fujita T, Shiba H, Kurihara H: Distinction Between Cell Proliferation and Apoptosis Signals Regulated by Brain-Derived Neurotrophic Factor in Human Periodontal Ligament Cells and Gingival Epithelial Cells. J Cell Biochem, 117: 1543-1555, 2016.

20) Nagayasu-Tanaka T, Anzai J, Takaki S, Shiraishi N, Terashima A, Asano T, Nozaki T, Kitamura M, Mura kami S: Action Mechanism of Fibroblast Growth Factor-2 (FGF-2) in the Promotion of Periodontal Regeneration in Beagle Dogs. PLoS One, 10: e0131870, 2015.

21) Takayama S, Yoshida J, Hirano H, Okada H, Mura kami S: Effects of basic fibroblast growth factor on human gingival epithelial cells. J Periodontol, 73: 14671473, 2002.

22) Sasaki S, Takeda K, Takewaki M, Ouhara K, Kajiya M, Mizuno N, Fujita T, Kurihara H: BDNF / HMW-HA complex as an adjunct to nonsurgical periodontal treatment of ligature-induced periodontitis in dogs. J Periodontol, 90: 98-109, 2019

23) Iwata $T$, Yamato $M$, Ishikawa $I$, Ando $T$, Okano $T$ : Tissue engineering in periodontal tissue. Anat Rec (Hoboken), 297: 16-25, 2014.

24) Kajiya M, Takeshita K, Kittaka M, Matsuda S, Ouhara K, Takeda K, Takata T, Kitagawa M, Fujita T, Shiba H, Kurihara H: BDNF mimetic compound LM22A-4 regulates cementoblast differentiation via the TrkBERK / Akt signaling cascade. Int Immunopharmacol, 19: 245-252, 2014. 
25) Pittenger MF, Mackay AM, Beck SC, Jaiswal RK, Douglas R, Mosca JD, Moorman MA, Simonetti DW, Craig S, Marshak DR: Multilineage potential of adult human mesenchymal stem cells. Science (New York, NY), 284: 143-147, 1999.

26) Kawaguchi H, Hirachi A, Hasegawa N, Iwata $T$, Hamaguchi H, Shiba H, Takata T, Kato Y, Kurihara H: Enhancement of periodontal tissue regeneration by transplantation of bone marrow mesenchymal stem cells. J Periodontol, 75: 1281-1287, 2004.

27) Samsonraj RM, Raghunath M, Nurcombe V, Hui JH, van Wijnen AJ, Cool SM: Concise Review: Multifaceted Characterization of Human Mesenchymal Stem Cells for Use in Regenerative Medicine. Stem Cells Transl Med, 6: 2173-2185, 2017.

28) Seo BM, Miura M, Gronthos S, Bartold PM, Batouli S, Brahim J, Young M, Robey PG, Wang CY, Shi S: Investigation of multipotent postnatal stem cells from human periodontal ligament. Lancet, 364: 149-155, 2004.

29) Novello S, Debouche A, Philippe M, Naudet F, Jeanne S: Clinical application of mesenchymal stem cells in periodontal regeneration: A systematic review and meta-analysis. J Periodontal Res, 55: 1-12, 2020.

30) Iwata $T$, Yamato M, Washio K, Yoshida T, Tsumanuma Y, Yamada A, Onizuka S, Izumi Y, Ando T, Okano T, Ishikawa I: Periodontal regeneration with autologous periodontal ligament-derived cell sheets A safety and efficacy study in ten patients. Regen Ther, 9: 38-44, 2018.

31) Okuda K, Yamamiya K, Kawase T, Mizuno H, Ueda M, Yoshie H: Treatment of human infrabony periodontal defects by grafting human cultured periosteum sheets combined with platelet-rich plasma and porous hydroxyapatite granules: case series. J Int Acad Periodontol, 11: 206-213, 2009.

32) Nagahara T, Yoshimatsu S, Shiba H, Kawaguchi H, Takeda K, Iwata T, Mizuno N, Fujita T, Kurihara H: Introduction of a mixture of beta-tricalcium phosphate into a complex of bone marrow mesenchymal stem cells and type I collagen can augment the volume of alveolar bone without impairing cementum regeneration. J Periodontol, 86: 456-464, 2015.

33) Xu XY, Li X, Wang J, He XT, Sun HH, Chen FM: Concise Review: Periodontal Tissue Regeneration Using Stem Cells: Strategies and Translational Considerations. Stem Cells Transl Med, 8: 392-403, 2019.

34) Larsson L, Decker AM, Nibali L, Pilipchuk SP, Berglundh T, Giannobile WV: Regenerative Medicine for Periodontal and Peri-implant Diseases. J Dent Res, 95: 255-266, 2016.
35) Hannachi IE, Yamato M, Okano T: Cell sheet technology and cell patterning for biofabrication. Biofabrication, 1: 022002, 2009.

36) Cesarz Z, Tamama K: Spheroid Culture of Mesenchymal Stem Cells. Stem Cells Int, 2016: 9176357, 2016.

37) Kittaka M, Kajiya M, Shiba H, Takewaki M, Takeshita K, Khung R, Fujita T, Iwata T, Nguyen TQ, Ouhara K, Takeda K, Fujita T, Kurihara H: Clumps of a mesenchymal stromal cell/extracellular matrix complex can be a novel tissue engineering therapy for bone regeneration. Cytotherapy, 17: 860-873, 2015.

38) Takewaki M, Kajiya M, Takeda K, Sasaki S, Motoike S, Komatsu N, Matsuda S, Ouhara K, Mizuno N, Fujita T, Kurihara H: MSC/ECM Cellular Complexes Induce Periodontal Tissue Regeneration. J Dent Res, 96: 984991, 2017.

39) Motoike S, Kajiya M, Komatsu N, Horikoshi S, Ogawa T, Sone H, Matsuda S, Ouhara K, Iwata T, Mizuno N, Fujita T, Ikeya M, Kurihara H: Clumps of Mesenchymal Stem Cell/Extracellular Matrix Complexes Generated with Xeno-Free Conditions Facilitate Bone Regeneration via Direct and Indirect Osteogenesis. Int J Mol Sci, 20: 2019.

40) Motoike S, Kajiya M, Komatsu N, Takewaki M, Hori koshi S, Matsuda S, Ouhara K, Iwata T, Takeda K, Fujita T, Kurihara H: Cryopreserved clumps of mesenchymal stem cell/extracellular matrix complexes retain osteogenic capacity and induce bone regeneration. Stem Cell Res Ther, 9: 73, 2018.

41) Krampera M, Cosmi L, Angeli R, Pasini A, Liotta F, Andreini A, Santarlasci V, Mazzinghi B, Pizzolo G, Vinante F, Romagnani P, Maggi E, Romagnani S, Annunziato $\mathrm{F}$ : Role for interferon-gamma in the immunomodulatory activity of human bone marrow mesenchymal stem cells. Stem Cells, 24: 386-398, 2006.

42) Takeshita K, Motoike S, Kajiya M, Komatsu N, Takewaki M, Ouhara K, Iwata T, Takeda K, Mizuno N, Fujita T, Kurihara H: Xenotransplantation of interferon-gamma-pretreated clumps of a human mesenchymal stem cell/extracellular matrix complex induces mouse calvarial bone regeneration. Stem Cell Res Ther, 8: 101, 2017.

43) Ouchi T, Nakagawa T: Mesenchymal stem cell-based tissue regeneration therapies for periodontitis. Regen Ther, 14: 72-78, 2020.

44) Zhao C, Ikeya M: Generation and Applications of Induced Pluripotent Stem Cell-Derived Mesenchymal Stem Cells. Stem Cells Int, 2018: 9601623, 2018.

45) Komatsu N, Kajiya M, Motoike S, Takewaki M, Hori koshi S, Iwata T, Ouhara K, Takeda K, Matsuda S, Fuji 
ta T, Kurihara H: Type I collagen deposition via osteoinduction ameliorates YAP/TAZ activity in $3 \mathrm{D}$ floating culture clumps of mesenchymal stem cell/extracellular matrix complexes. Stem Cell Res Ther, 9: 342, 2018

46) Komatsu N, Kajiya M, Morimoto S, Motoike S, Yoshii
H, Iwata T, Ouhara K, Matsuda S, Mizuno N, Kurihara H: Cox2-mediated PGE2 production via p38/JNK-c-fos signaling inhibits cell apoptosis in 3D floating culture clumps of mesenchymal stem cell/extracellular matrix complexes. Biochem Biophys Res Commun, 530: 448-454, 2020.

\title{
Basic research on cytokine and cell therapy to establish a novel promising strategy for periodontal tissue regeneration
}

\author{
Mikihito Kajiya \\ Department of Periodontal Medicine, Graduate School of Biomedical \& Sciences, Hiroshima University
}

\begin{abstract}
Periodontitis is an inflammatory disease attributed to host immune responses to periodontal pathogenic bacteria, characterized by destruction of periodontal tissues, including the cementum, periodontal ligament, and alveolar bone. If left untreated, periodontitis can result in irreversible tissue damage, leading to tooth loss. Thus, periodontal treatment is aimed at controlling bacterial infection. However, while elimination of infection can attenuate the inflammatory condition and interrupt the progression of tissue destruction, it is rarely effective at inducing periodontal tissue regeneration. Importantly, after periodontal treatment, patients are prone to recurrent periodontitis due to reduced cleanability caused by a disrupted gingival line and secondary occlusal damage resulting from lack of supportive tissue. Accordingly, for obtaining full recovery from periodontal disease, successful periodontal tissue regenerative therapy is required.

Much scientific effort has been expended over several decades to develop periodontal tissue regenerative therapy and bone grafts, barrier membranes, and enamel matrix-derivatives have frequently been applied clinically as periodontal tissue regenerative therapy. Furthermore, basic researches focused on biomaterials, cytokines, and stem cells have accelerated the development of reliable periodontal tissue regenerative therapy in the 21 st century. In fact, cytokine therapy with the application of recombinant basic fibroblast growth factor has been established in Japan. In addition, several clinical trials using mesenchymal stem cells have been conducted and reported success.

Notwithstanding the aforementioned advances and introduction of novel technologies, there are still numerous issues that need to be resolved by basic research to provide safer, more effective, and reliable periodontal tissue regenerative therapy to all periodontitis patients. Therefore, in this review article, the history and current status of development of cytokine and cell therapies are outlined. Then, solutions for the development of promising periodontal tissue regenerative therapies are introduced, including the efforts of the author's research group. Finally, the latest scientific findings are reviewed, and future research issues to be addressed are discussed.
\end{abstract}

Key words: periodontal tissue regeneration, cytokine therapy, cell therapy, mesenchymal stem cells

Corresponding author: Mikihito Kajiya

Department of Periodontal Medicine, Graduate School of Biomedical \& Sciences, Hiroshima University

1-2-3 Kasumi, Minami-Ku, Hiroshima 734-8553, Japan

E-mail: mkajiya@hiroshima-u.ac.jp 